\title{
Analisa Perbandingan Laju Korosi di Lingkungan Laut dari Hasil Pengelasan GMAW pada Sambungan Aluminium Seri 5050 karena Pengaruh Variasi Kecepatan Aliran Gas Pelindung
}

\author{
Pandu Damay Putra, Herman Pratikno, dan Yoyok Setyo H \\ Jurusan Teknik Kelautan, Fakultas Teknologi Kelautan, Institut Teknologi Sepuluh Nopember (ITS) \\ Jl. Arief Rahman Hakim, Surabaya 60111 Indonesia \\ e-mail: hermanp@oe.its.ac.id
}

\begin{abstract}
Abstrak - Penggunaan aluminium saat ini di dunia industri perkapalan sedang berkembang pesat untuk kapal-kapal cepat karena material ini ringan dan memiliki resistensi terhaap korosi yang baik. Aluminium seri $\mathbf{5 0 5 0}$ merupakan jenis material yang banyak digunakan dalam konstruksi kapal. Namun pengerjaan panas seperti pengelasan akan mempengaruhi struktur mikro material dan berpengaruh terhadap ketahanan korosi. Pengelasan GMAW (Gas Metal Arc Welding) merupakan pengelasan yang umum digunakan pada material aluminium karena meberikan perlindungan dari oksidasi dengan pencairan gas terhadap material lasan. Penelitian ini bertujuan untuk mengetahui pengaruh dari variasi kecepatan aliran gas pelindung terhadap laju korosi aluminium seri 5050. Variasi kecepatan aliran gas pelindung yang digunakan adalah 15, 20, dan 25 liter/menit. Metode pengujian korosi ini menggunakan bantuan sel tiga elektroda dengan media korosi larutan pengganti air laut dengan salinitas $3,5 \%$ yang mengacu pada ASTM G102. Dari pengujian ini didapatkan hasil laju korosi pada pengelasan aluminium dengan kecpatan aliran gas pelindung 15 liter/menit adalah 0,16 mmpy, untuk 20 liter/menit adalah 0,12 mmpy, dan untuk 25 liter/menit adalah 0,08 mmpy. Dari hasil pengujian dapat disimpulkan bahwa semakin besar aliran gas pelindung maka ketahanan material terhadap korosi semakin baik.
\end{abstract}

Kata Kunci- Aluminium Seri 5050, GMAW, Kecepatan aliran Gas Pelindung, Laju Korosi.

\section{PENDAHULUAN}

$\mathrm{P}$ EMBANGUNAN konstruksi kapal dengan material alumunium mengalami perkembangan yang cukup signifikan. Selain karena material ini ringan, alumunium juga mempunyai sifat resistensi terhadap korosi yang baik hal ini disebabkan karena terjadinya fenomena pasivasi. Fenomena pasivasi adalah terbentuknya lapisan aluminium oksida ketika aluminium terpapar dengan udara bebas, lapisan oksida ini yang mencegah terjadinya oksidasi lebih lanjut [1], sehingga material ini banyak dikembangkan untuk kapal-kapal cepat dan kapal militer.

Aluminium terdiri dari beberapa kelompok yang dibedakan berdasarkan paduan penyusunnya. Penambahan paduan ini akan menghasilkan sifat yang berbeda pula. Aluminium 5050 merupakan paduan aluminium dengan magnesuim $(\mathrm{Mg})$, paduan ini memiliki sifat tidak dapat diperlaku-panaskan, tetapi memiliki sifat yang baik dalam daya tahan korosi terutama korosi oleh air laut. Al-Mg banyak dipakai untuk konstruksi umum termasuk konstruksi kapal [2]. Namun paduan aluminium mempunyai sifat yang kurang baik dalam hal pengelasan bila dibandingkan dengan baja [3].

Proses pengelasan biasanya digunakan untuk fabrikasi dalam aplikasi teknik, misalnya untuk pesawat terbang, otomotif, dan industri perkapalan. Terlepas dari sifat mampu las aluminium, perkembangan teknologi pengelasan berjalan dengan pesat. Terutama pengelasan busur listrik dengan pelindung gas mulia, telah menjadikan sifat mampu las aluminium menjadi lebih baik. Proses pengelasan yang sering digunakan untuk pengelasan aluminium adalah gas metal arc welding (GMAW) atau yang lebih dikenal dengan las metal inert gas MIG. Jenis las ini sangat baik untuk menyambung logam aluminium karena proses las ini menggunakan prinsip di lingkungan gas mulia yang dilengkapi consumable metal electrode, di mana elektroda ini gunanya untuk menyalakan busur listrik. Gas pelindung yang digunakan pada pengelasan GMAW atau MIG adalah argon, helium atau campuran di antara keduannya. Fungsi dasar dari gas pelindung adalah melindungi busur dan logam las cair dari kontaminasi oksigen dan nitrogen yang ada pada atmosfer. Jika aliran gas pelindung tidak tepat melindungi logam las cair maka akan dihasilkan cacat las seperti porositas, slag inclusion, embrittlement. Maka akan menyebabkan perubahan struktur mikro, sehingga terjadi perubahan sifat mekanik hasil lasan [3].

Namun Pengerjaan panas seperti proses pengelasan memberikan pengaruh terhadap laju korosi yang terjadi pada material aluminium [4]. Panas yang timbul selama proses pengelasan dapat menyebabkan terjadinya perubahan struktur pada daerah terpengaruh panas $(\mathrm{HAZ}=$ Heat Affected Zone $)$ [5]. Pada studi eksperimen ini diteliti bagaimana hasil perbandingan dari proses pengelasan metode GMAW terhadap laju korosi pada sambungan aluminium seri 5050 di lingkungan laut dengan variasi kecepatan aliran gas pelindung. 


\section{METODE PENELITIAN}

\section{A. Tahap Persiapan Spesimen dan Pengelasan}

Material yang digunakan adalah pelat aluminium seri 5050 . Spesimen uji dibuat berbentuk segi empat dengan ukuran panjang $300 \mathrm{~mm}$, lebar $150 \mathrm{~mm}$ dan tebal $12 \mathrm{~mm}$ dengan kampuh double v-groove sesuai standar [6].

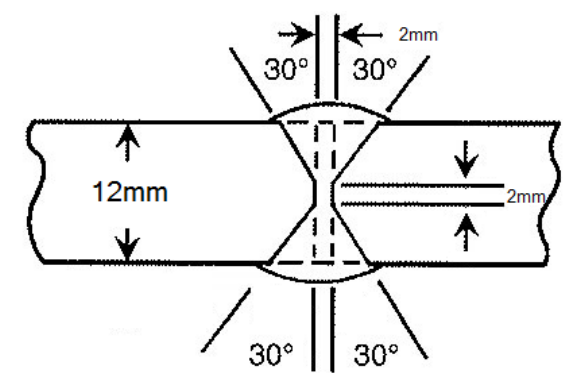

Gambar 1. Bentuk dan ukuran kampuh spesimen (double v-groove)

Pada penelitian kali ini dilakukan pengelasan gas metal arc welding (GMAW) menggunakan ER5356 sebagai elektroda dan gas argon dengan kemurnian $99.99 \%$ sebagai gas pelindung [6]. Variasi kecepatan aliran gas pelindung yang digunakan untuk pengujian kali ini adalah 15,20 dan 25 liter/menit.

\section{B. Tahap Inspeksi}

Setelah proses pengelasan dilakukan inspeksi atau pengujian. Pengujian secara Non Destructive Test (NDT) dengan menggunakan Radiographic Testing yang berpedoman kepada standar [6]. Pengujian radiografi ini dilakukan di PT. Robutech Surabaya yang beralamat di Semolowaru Selatan V No.25, Sukolilo, Kota Surabaya, Jawa Timur.

\section{Tahap Pembuatan Spesimen dan Pengujian}

- Pengujian metalografi dilakukan di Laboratorium Konstruksi dan Kekuatan Kapal Teknik Perkapalan FTKITS Surabaya. Pengujian metalografi dibagi menjadi dua yaitu pengujian makro dan pengujian mikro. Pada pengujian metalografi kali ini dibuat sebanyak 1 spesimen (untuk masing-masing variasi kecepatan aliran gas pelindung) sehingga jumlah spesimen yang digunakan untuk uji metalografi sebanyak 3 spesimen yang harus dilakukan polishing dan pengolesan dengan cairan etsa $(15 \mathrm{~mL} \mathrm{HCl}$ $10 \mathrm{~mL}$ HF dan $85 \mathrm{~mL}$ air accu) [7]. Pengujian metalografi ini bertujuan untuk mengetahui hasil mikrostruktur dari material dan mengetahui kualitas hasil las-lasan.

- Pengujian Tarik dilakukan di Laboratorium Konstruksi dan Kekuatan Kapal Teknik Perkapalan FTK-ITS Surabaya. Pada pengujian tarik kali ini dibuat sebanyak 3 spesimen (untuk masing-masing variasi kecepatan aliran gas pelindung) sehingga jumlah spesimen yang digunakan untuk uji tarik sebanyak 9 spesimen yang setiap spesimen uji tarik dibentuk berdasarkan standar [6]. Pengujian tarik ini bertujuan untuk mengetahui nilai kuat tarik dari material dan mengetahui kualitas hasil las-lasan.

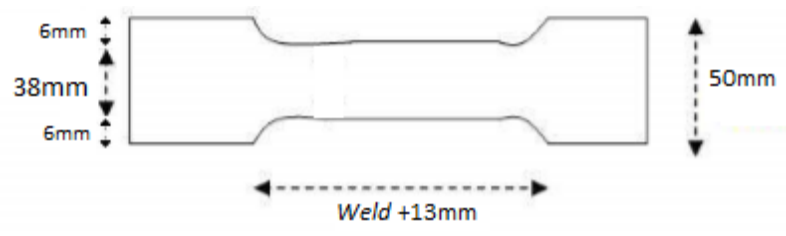

Gambar 2. Bentuk dan ukuran spesimen uji tarik

- Pengujian kekerasan dilakukan di Laboratorium Konstruksi dan Kekuatan Kapal Teknik Perkapalan FTK-ITS Surabaya. Pengujian kekerasan yang digunakan adalah uji kekerasan vickers yang bertujuan untuk mengetahui nilai kekerasan dari material dan mengetahui kualitas hasil las-lasan.Pada pengujian kekerasan kali ini dibuat sebanyak 1 spesimen (untuk masing-masing variasi kecepatan aliran gas pelindung) sehingga jumlah spesimen yang digunakan untuk uji kekerasan sebanyak 3 spesimen [8].

- Pengujian korosi dilakukan di Laboratorium Elektrokimia dan Korosi Teknik Kimia FTI-ITS menggunakan potensiostat sel tiga elektroda yang terhubung dengan software NOVA berdasarkan satandar [9]. Pemotongan spesimen uji korosi dengan ukuran $(50 \mathrm{~mm} \times 12 \mathrm{~mm} \times 10$ $\mathrm{mm}$ ) sebanyak 3 spesimen (untuk masing-masing variasi kecepatan aliran gas pelindung). Sehingga jumlah spesimen yang digunakan untuk uji korosi sebanyak 9 spesimen ditambah dengan material induk 3 spesimen jadi jumlahnya 12 spesimen. Setelah spesimen dibuat maka diberi pembatas menggunakan bahan yang kedap air pada sisinya karena pada pengujian korosi, spesimen yang akan diuji korosi adalah daerah logam lasnya saja. Pada percobaan ini digunakan larutan kimia sebagai pengganti air laut dengan salinitas $3.5 \%$ sesuai standar [10].

\section{HASIL DAN PEMBAHASAN}

\section{A. Hasil Pengujian Metalografi}

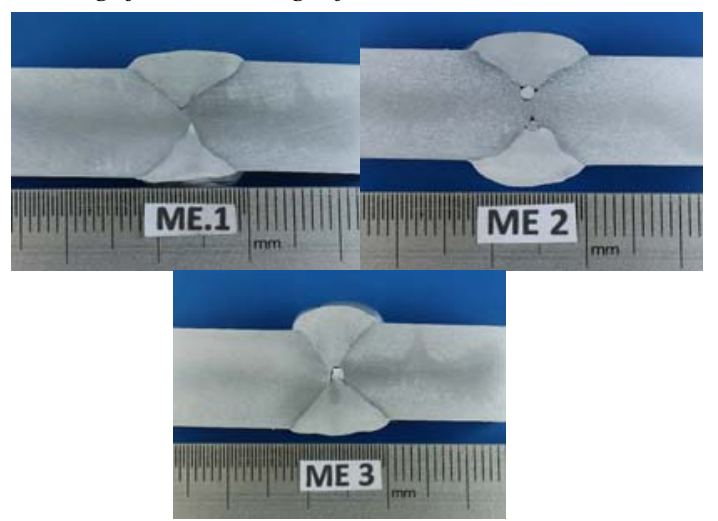

Gambar 3. Hasil Uji Makro 15, 20 dan 25 liter/menit

Dari Gambar 3 spesimen uji makro dapat diambil kesimpulan yaitu:

1. Terjadi incomplete penetration pada semua variasi sambungan las-lasan GMAW dikarenakan tidak dilakukan perlakuan panas sebelum dan sesudah pengelasan dan penggunaan gerinda saat melakukan pengelasan aluminium yang tidak sesuai standar.

2. Ada indikasi terjadi porositas pada hasil pengelasan karena 
terlihat ada seperti butir butir kecil yang disebabkan oleh pengaruh lingkungan saat pengelasan. Namun yang paling terlihat adalah terdapat cacat incomplete penetration.

Presentase mikrostruktur spesimen bisa dihitung menggunakan metode point counting yaitu dengan cara menghitung jumlah titik yang ada dalam suatu fasa dibagi dengan jumlah seluruh titik. Titik tersebut didapat dari sebuah grid. Grid yang digunankan adalah grid dengan total titiknya 9, 16, 25 dan 100. Untuk yang memiliki fraksi volume yang tinggi, lebih efektif menggunakan grid dengan densitas titik yang rendah dan sebaliknya [11]. Berikut adalah rumus penghitungan dengan metode point counting.

$$
\mathrm{P}_{\mathrm{P}}=\frac{\sum \mathrm{P}_{\mathrm{u}}}{\mathrm{P}_{\mathrm{T}}}=\frac{\sum \mathrm{P}_{u}}{\mathrm{n} \mathrm{P}_{0}}
$$

Di mana:

$\mathrm{P}_{\mathrm{T}}=\mathrm{nP}_{\mathrm{o}}=$ jumlah titik

$\mathrm{P} \alpha=$ jumlah titik di fasa $\alpha$

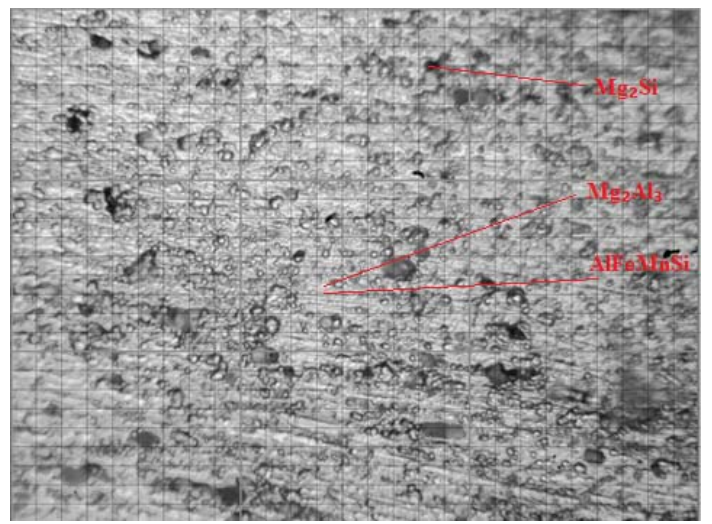

Gambar 4. Plotting grid untuk penghitungan presentase mikrostruktur dengan metode point counting

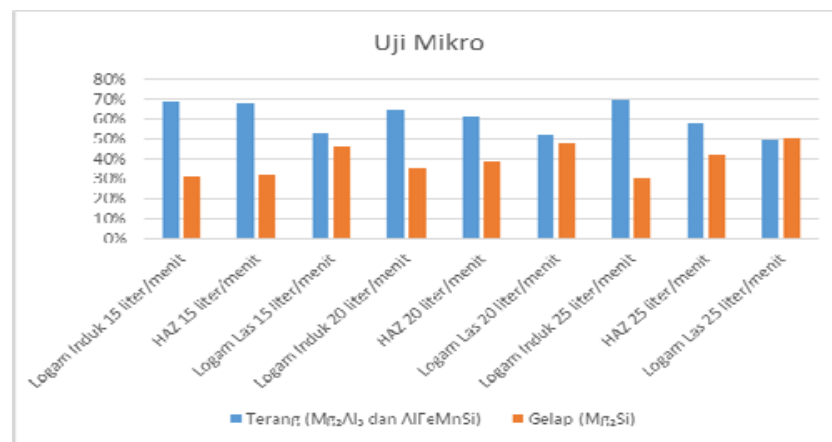

Gambar 5. Diagram perbadingan rata-rata presentase hasil uji mikro

Gambar 4 menunjukkan struktur mikro dari alumunium 5050, dimana alumunium yang berisi silikon ( $\mathrm{Si}$ ) mempunyai kepekaan dalam membentuk formasi presipitat $\mathrm{Mg}_{2} \mathrm{Si}$, pembentukan $\mathrm{Mg}_{2} \mathrm{Si}$ ini dapat meningkatkan kekuatan tarik dan kekerasan pada alumunium [12]. Pada Gambar 5 rata-rata hasil mikrostruktur gambar dapat disimpulkan bahwa presentase terang $\left(\mathrm{Mg}_{2} \mathrm{Al}_{3}\right.$ dan $\left.\mathrm{AlFeMnSi}\right)$ lebih besar dari presentase gelap $\left(\mathrm{Mg}_{2} \mathrm{Si}\right)$ di daerah material induk. Namun semakin mendekati daerah HAZ dan logam las presentase terang $\left(\mathrm{Mg}_{2} \mathrm{Al}_{3}\right.$ dan $\left.\mathrm{AlFeMnSi}\right)$ semakin menurun dan presentase gelap $\left(\mathrm{Mg}_{2} \mathrm{Si}\right)$ semakin meningkat.

\section{B. Hasil Pengujian Tarik}

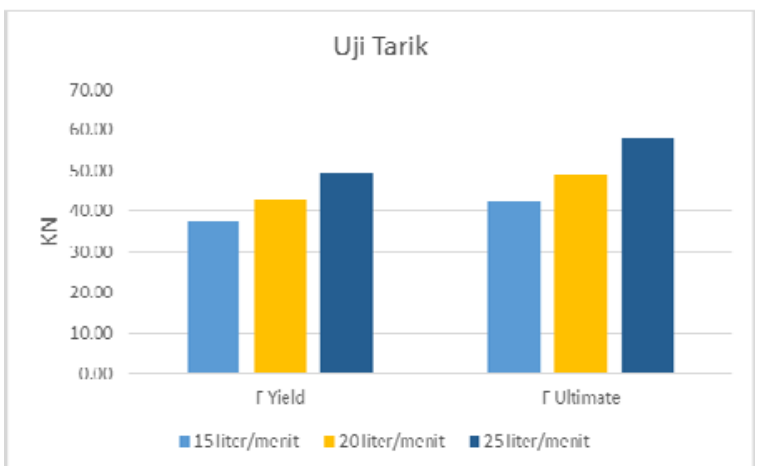

Gambar 6. Perbandingan grafik F Yield dan F Ultimate spesimen variasi kecepatan aliran gas pelindung 15, 20, dan 25 liter/menit

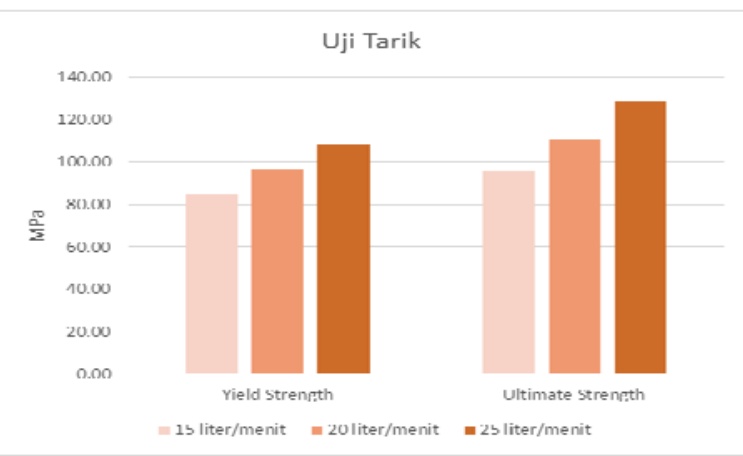

Gambar 7. Perbandingan grafik Yield Strength dan Ultimate Strength spesimen variasi aliran gas pelindung 15, 20, dan 25 liter/menit

Gambar 6 dan 7 menjelaskan bahwa pengelasan yang dihasilkan dari metode GMAW dengan kecepatan aliran gas pelindung 25 liter/menit lebih kuat dan padat dibandingkan dengan kecepatan aliran gas pelindung 15 liter/menit dan 20 liter/menit karena material dapat putus dengan waktu lebih lama dengan beban maksimal rata-rata $58,17 \mathrm{kN}$ dan ultimate strength $128.31 \mathrm{MPa}$ sedangkan pada uji tarik untuk pengelasan metode GMAW dengan kecepatan aliran gas pelindung 15 liter/menit dan 20 liter/menit membutuhkan waktu lebih singkat dengan rata-rata beban maksimal dan ultimate strength yang lebih kecil yaitu $42,3 \mathrm{kN}, 49 \mathrm{kN}$ dan 95.32 MPa, $110.18 \mathrm{MPa}$.

Jadi material aluminium seri 5050 yang dilas dengan metode pengelasan GMAW dengan kecepatan aliran gas pelindung 25 liter/menit memiliki hasil pengelasan yang lebih elastis atau ulet jika dibandingkan dengan hasil pengelasan GMAW dengan kecepatan aliran gas pelindung 15 liter/menit dan 20 liter/menit yang lebih getas. Hasil ini menjelaskan korelasi yang tepat jika dibandingkan dengan hasil uji metalografi.

\section{Hasil Pengujian Kekerasan}

Pada pengujian kekerasan bertujuan untuk mengetahui kemampuan benda dalam menerima pembebanan atau identasi dengan beban dan waktu yang telah ditentukan sebelumnya. Untuk pengujian kekerasan vickers pada spesimen ini direncanakan pada Gambar 8. 


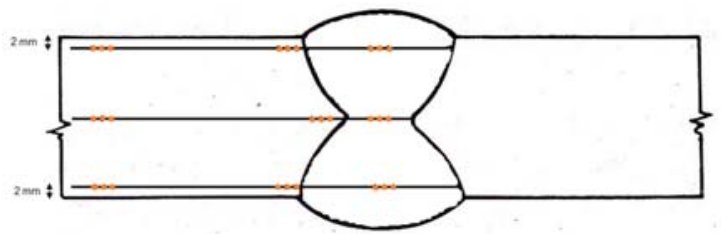

Gambar 8. Titik uji kekerasan vickers

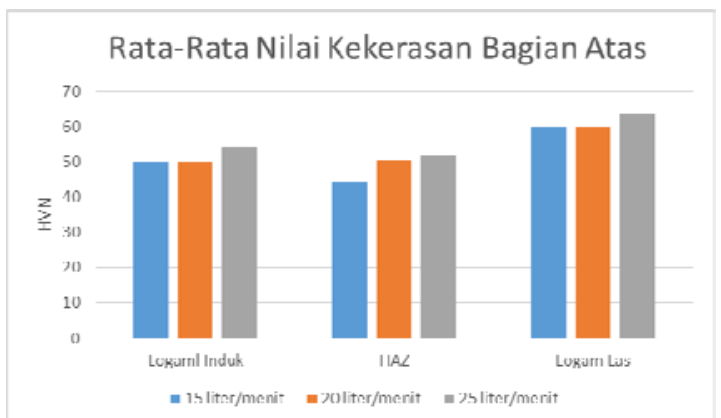

Gambar 9. Perbandingan grafik rata-rata nilai kekerasan vickers bagian atas spesimen variasi aliran gas pelindung 15, 20, dan 25 liter/menit

Gambar 9 menunjukkan analisa di bagian atas spesimen untuk nilai tertinggi pada logam las, HAZ, dan logam induk terdapat saat variasi kecepatan aliran gas pelindung 25 liter/menit yaitu sebesar $63,93 \mathrm{HVN}$ untuk logam las 51,83 HVN untuk HAZ dan 54,13 HVN untuk logam induk lalu kecepatan aliran gas pelindung 20 liter/menit sebesar 60,17 HVN untuk lolgam las 50,77 HVN untuk HAZ dan 49,83 HVN untuk logam induk dan yang terendah pada kecepatan aliran gas pelindung 15 liter/menit sebesar $59,77 \mathrm{HVN}$ untuk logam las 44,4 HVN untuk HAZ dan 49,77 HVN untuk logam induk.

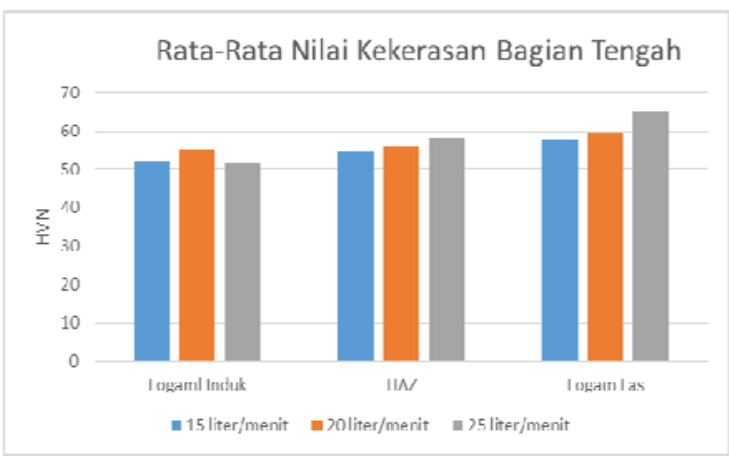

Gambar 10. Perbandingan grafik rata-rata nilai kekerasan vickers bagian temgah spesimen variasi aliran gas pelindung 15, 20, dan 25 liter/menit

Gambar 10 menunjukkan analisa di bagian tengah spesimen untuk nilai tertinggi pada logam las, HAZ, dan logam induk terdapat saat variasi kecepatan aliran gas pelindung 25 liter/menit yaitu sebesar $64,9 \mathrm{HVN}$ untuk logam las 58,07 HVN untuk HAZ dan 51,83 HVN untuk logam induk lalu kecepatan aliran gas pelindung 20 liter/menit sebesar 59,20 HVN untuk logam las 56,03 HVN untuk HAZ dan 55,27 HVN untuk logam induk dan yang terendah pada kecepatan aliran gas pelindung 15 liter/menit sebesar 57,83 HVN untuk logam las 54,93 HVN untuk HAZ dan 52,13 HVN untuk logam induk.

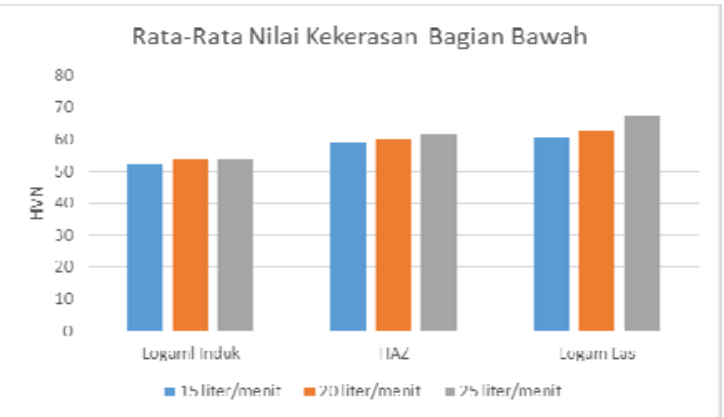

Gambar 11. Perbandingan grafik rata-rata nilai kekerasan vickers bagian bawah spesimen variasi aliran gas pelindung 15, 20, dan 25 liter/menit

Gambar 11 analisa di bagian bawah spesimen untuk nilai tertinggi pada logam las, HAZ, dan logam induk terdapat saat variasi kecepatan aliran gas pelindung $25 \mathrm{liter} /$ menit yaitu sebesar 67,33 HVN untuk logam las 61,7 HVN untuk HAZ dan 53,8 HVN untuk logam induk lalu kecepatan aliran gas pelindung 20 liter/menit sebesar 62,8 HVN untuk logam las 59,9 HVN untuk HAZ dan 53,73 HVN untuk logam induk dan yang terendah pada kecepatan aliran gas pelindung 15 liter/menit sebesar 66,43 HVN untuk logam las 59,4 HVN untuk HAZ dan 52,03 HVN untuk logam induk.

Jadi material aluminium seri 5050 yang dilas dengan metode pengelasan GMAW dengan kecepatan aliran gas pelindung 25 liter/menit memiliki nilai kekerasan yang lebih besar jika dibandingkan dengan hasil pengelasan GMAW dengan kecepatan aliran gas pelindung 15 liter/menit dan 20 liter/menit. Hasil ini menjelaskan korelasi yang tepat jika dibandingkan dengan hasil uji metalografi [10].

\section{Hasil Pengujian Korosi}

Pengujian korosi dilakukan dengan menggunakan metode sel tiga elektroda dengan bantuan seperangkat peralatan Potensiostat Autolab (PGSTAT30) dan software NOVA. Secara otomatis software akan menunjukkan laju korosi dari benda yang diuji. Data lain yang didapat dari pengujian ini meliputi nilai rapat arus dan potensial. Selain material itu sendiri data lain yang dibutuhkan untuk melakukan pengujian yaitu massa jenis $(\mathrm{g} / \mathrm{cm} 3)$, equivalent weight $(\mathrm{g} / \mathrm{mol})$, dan area yang terendam oleh larutan elektrolit $(\mathrm{cm} 2)$. Dari hasil pengujian akan didapat diagram tafel yaitu diagram yang menunjukkan potensial dan kerapatan arus yang digunakan oleh peralatan uji korosi terhadap spesimen untuk menentukan laju korosi material.

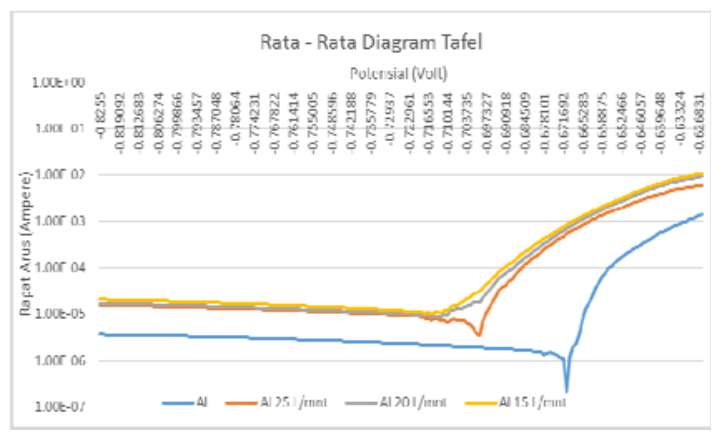

Gambar 12. Rata-rata diagram tafel spesimen

Gambar 12 menjelaskan tentang hasil rata-rata diagram tafel 
dari semua pengujian spesimen dengan variasi kecepatan aliran gas pelindung 15, 20 dan 25 liter/menit. Grafik yang memiliki nilai puncak semakin negatif atau potensial yang semakin negatif berarti memiliki laju korosi yang tinggi dan sebaliknya. Dari grafik tersebut dapat disimpulkan bahwa laju korosi yang paling kecil adalah spesimen tanpa pengelasan dengan rata-rata potensial $665.43 \mathrm{~V}$, kecepatan aliran gas pelindung 25 liter/menit dengan rata-rata potensial $702.75 \mathrm{~V}$, kecepatan aliran gas pelindung 20 liter/menit dengan rata-rata potensial $708 \mathrm{~V}$ dan terakhir kecepatan aliran gas pelindung 15 liter/menit dengan rata-rata potensial $729.72 \mathrm{~V}$.

Tabel 1. Hasil pengujian korosi menggunakan software NOVA

\begin{tabular}{|c|c|c|c|c|c|}
\hline $\begin{array}{c}\text { Material } \\
\text { Pengelasan }\end{array}$ & Spesimen & $\begin{array}{l}\text { i corr }\left(\mu \mathrm{A} / \mathrm{cm}^{2}\right) \\
\text { NOVA }\end{array}$ & $\begin{array}{c}\text { Rata-rata i corr } \\
\left(\mu \mathrm{A} / \mathrm{cm}^{2}\right)\end{array}$ & $\begin{array}{c}\text { Laju Korosi } \\
\text { (mmpy) NOVA }\end{array}$ & $\begin{array}{c}\text { Rata-rata } \\
\text { (mmpy) }\end{array}$ \\
\hline \multirow{3}{*}{$\begin{array}{l}\text { Aluminium } \\
\text { Seri } 5050 \\
\text { (Material } \\
\text { Induk) }\end{array}$} & $\mathrm{c}_{2}$ & 4.04821 & \multirow{3}{*}{4.2574} & 0.0443 & \multirow{3}{*}{0.0464} \\
\hline & $\mathrm{C}_{2}$ & 4.52115 & & 0.0487 & \\
\hline & $\mathrm{C}_{2}$ & 4.20283 & & 0.0459 & \\
\hline \multirow{4}{*}{$\begin{array}{l}\text { Aluminium } \\
\text { Seri 5050 } \\
\text { (GMAW-15 } \\
\text { liter/menit) }\end{array}$} & & & \multirow{4}{*}{14.42925} & & \\
\hline & $C_{4}$ & 15.54012 & & 0.16981 & \multirow{3}{*}{0.1580} \\
\hline & c, & 15.25251 & & 0.16752 & \\
\hline & $\mathrm{C}_{0}$ & 12.49511 & & 0.13668 & \\
\hline \multirow{3}{*}{$\begin{array}{l}\text { Aluminium } \\
\text { Seri } 5050 \\
\text { (GMAW-20 } \\
\text { liter /menit) }\end{array}$} & $c_{-}$ & 9.68882 & \multirow{3}{*}{10.83448} & 0.10588 & \multirow{3}{*}{0.1187} \\
\hline & $\frac{C_{7}}{C_{8}}$ & $\begin{array}{l}10.00002 \\
10.82211\end{array}$ & & 0.11899 & \\
\hline & c, & 11.99251 & & 0.13115 & \\
\hline \multirow{3}{*}{$\begin{array}{l}\text { Aluminium } \\
\text { Seri } 5050 \\
\text { (GMAW-25 } \\
\text { liter/menit) }\end{array}$} & $\mathrm{C}_{10}$ & 7.55566 & \multirow{3}{*}{7.54418} & 0.08211 & \multirow{3}{*}{0.0823} \\
\hline & $\mathrm{C}_{11}$ & 8.53558 & & 0.09337 & \\
\hline & $C_{22}$ & 6.54129 & & 0.07155 & \\
\hline
\end{tabular}

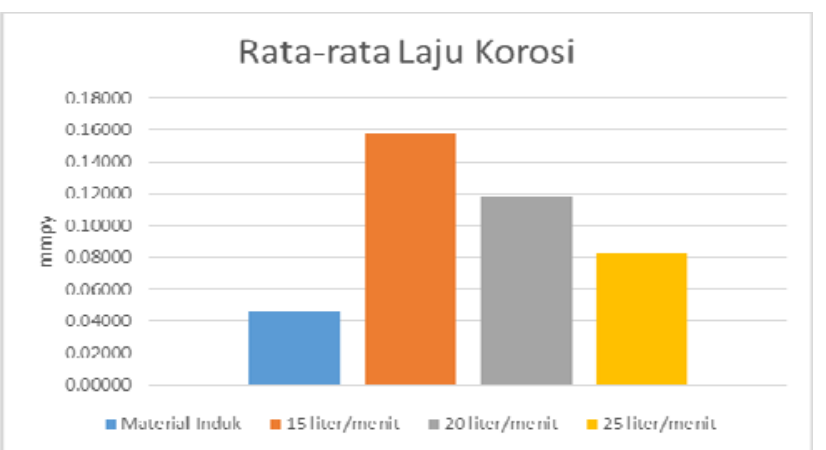

Gambar 13. Diagram perbandingan rata-rata laju korosi (mmpy) setiap variasi kecepatan aliran gas pelindung

Dari data Tabel 1 dan Gambar 13 dapat diketahui nilai laju korosi spesimen, yaitu semakin kecil kecepatan aliran gas pelindung maka nilai laju korosinya akan semakin besar. Pada tabel dapat dilihat nilai laju korosi tertinggi adalah spesimen dengan kecepatan aliran gas pelindung 15 liter/menit yaitu 0.158 mmpy. Sedangkan nilai laju korosi terendah adalah spesimen dengan kecepatan aliran gas pelindung 25 liter/menit yaitu $0.0823 \mathrm{mmpy}$ (material induk tidak diperhitungkan). Hal ini menunjukkan bahwa nilai laju korosi berbanding lurus dengan nilai rapat arus yaitu semakin besar rapat arus pada spesimen maka laju korosi pada spesimen tersebut juga ikut membesar dan sebaliknya semakin kecil rapat arus pada spesimen maka laju korosi pada spesimen tersebut juga ikut mengecil.

\section{E. Hukum Faraday}

Dari data hasil pengujian laju korosi dengan menggunakan software NOVA selain didapatkan nilai laju korosi juga diperoleh nilai rapat arus yang selanjutnya nilai dari rapat arus tersebut dimasukkan ke dalam rumus Hukum Faraday sebagai berikut:

Eaju EQrast $=\frac{K \times a \times t}{n \times D}$

Laju korosi dengan satuan mmpy, di mana:

$\mathrm{a}=$ Berat atom logam yang terkorosi $(\mathrm{gram} / \mathrm{mol})=26.98$ untuk $\mathrm{Al}$

$\mathrm{i}=\mathrm{i} \operatorname{corr}\left(\mu \mathrm{A} / \mathrm{cm}^{2}\right)$

$\mathrm{k}=$ konstanta $(0.00327$ untuk mmpy)

$\mathrm{n}=$ jumlah elektron yang dilepas pada logam terkorosi $=3$

$\mathrm{D}=$ masa jenis logam terkorosi $\left(\mathrm{gram} / \mathrm{cm}^{3}\right)=2.69$ untuk $\mathrm{Al}$

Tabel 2. Hasil pengujian korosi menggunakan hukum faraday

\begin{tabular}{|c|c|c|c|c|}
\hline $\begin{array}{c}\text { Material } \\
\text { Pengelasan }\end{array}$ & Spesimen & $\begin{array}{l}\text { i corr }\left(\mu \mathrm{A} / \mathrm{cm}^{2}\right) \\
\text { NOVA }\end{array}$ & $\begin{array}{c}\text { Laju Korosi } \\
\text { (mmpy) Hukum } \\
\text { Faraday }\end{array}$ & $\begin{array}{c}\text { Rata-rata } \\
\text { (mmpy) }\end{array}$ \\
\hline \multirow{3}{*}{$\begin{array}{l}\text { Aluminium Seri } 5050 \\
\text { (Material Induk) }\end{array}$} & $\mathrm{C}_{1}$ & 4.04821 & 0.04426 & \multirow{3}{*}{0.0465} \\
\hline & $\mathrm{C}_{2}$ & 4.52115 & 0.04943 & \\
\hline & $\mathrm{C}_{3}$ & 4.20283 & 0.04595 & \\
\hline \multirow{3}{*}{$\begin{array}{l}\text { Aluminium Seri } 5050 \\
\text { (GMAW-15 } \\
\text { liter/menit) }\end{array}$} & $\mathrm{C}_{4}$ & 15.54012 & 0.16989 & \multirow{3}{*}{0.1577} \\
\hline & c, & 15.25251 & 0.16675 & \\
\hline & $\mathrm{C}_{0}$ & 12.49511 & 0.13661 & \\
\hline \multirow{3}{*}{$\begin{array}{c}\text { Aluminium Seri } 5050 \\
\text { (GMAW-20 } \\
\text { liter/menit) }\end{array}$} & $\mathrm{C}_{7}$ & 9.68882 & 0.10592 & \multirow{3}{*}{0.1185} \\
\hline & $\mathrm{C}_{8}$ & 10.82211 & 0.11831 & \\
\hline & c, & 11.99251 & 0.13111 & \\
\hline \multirow{3}{*}{$\begin{array}{c}\text { Aluminium Seri } 5050 \\
\text { (GMAW-25 } \\
\text { liter menit) }\end{array}$} & $\mathrm{C}_{20}$ & 7.55566 & 0.0826 & \multirow{3}{*}{0.0825} \\
\hline & $\mathrm{C}_{11}$ & 8.53558 & 0.09331 & \\
\hline & $\mathrm{C}_{22}$ & 6.54129 & 0.07151 & \\
\hline
\end{tabular}

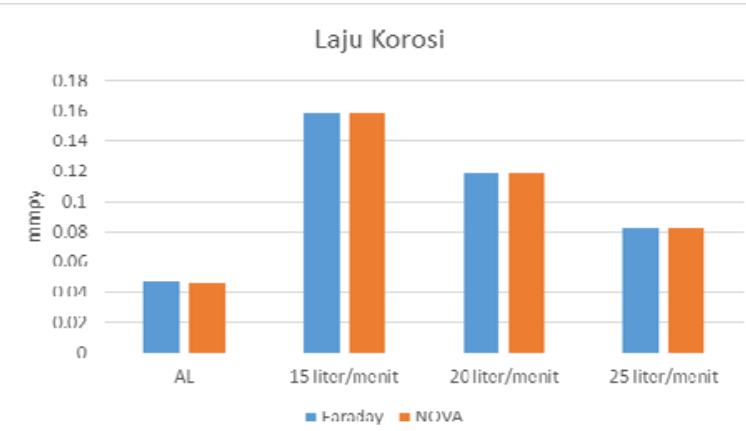

Gambar 14. Diagram perbandingan rata-rata laju korosi (mmpy) setiap variasi kecepatan aliran gas pelindung

Dari data Tabel 2 dan Gambar 14 yang diperoleh dari perhitungan rumus Hukum Faraday dan perbandingan yang diperoleh dengan software NOVA memiliki hasil yang hampir sama. Jadi dapat disimpulkan bahwa pengerjaan panas pada material aluminium akan mempengaruhi struktur mikro material dan menyebabkan daya tahan material terhadap laju korosi semakin menurun karena pemanasan pada saat pengelasan terjadi hanya pada daerah yang akan dilas saja atau disebut pemanasan lokal. Akibat pemanasan lokal dengan temperatur yang tinggi menyebabkan logam mengalami ekspansi termal. Sehingga, menyebabkan adanya tegangan sisa yang memicu terjadinya korosi. Selain itu kecepatan aliran gas pelindung juga mempengaruhi tingkat laju korosi spesimen di mana kecepatan aliran gas pelindung yang lebih 
tinggi yaitu 25 liter/menit memiliki daya tahan terhadap korosi yang lebih baik jika dibandingkan dengan kecepatan aliran gas pelindung sebesar 15 dan 20 liter/menit.

\section{KESIMPULAN}

Dari penelitian yang dilakukan yaitu hasil perbandingan dari proses pengelasan menggunakan metode GMAW (Gas Metal Arc Welding) dengan variasi kecepatan aliran gas pelindung terhadap ketahanan korosi pada sambungan aluminium seri 5050 dapat ditarik beberapa kesimpulan berdasarkan dari hasil pengujian yang telah dilakukan antara lain sebagai berikut:

1. Nilai kekerasan dan kekuatan material yang semakin tinggi, maka akan mempengaruhi terhadap laju korosi yang semakin mengecil.

-Aluminium seri 5050 dengan aliran gas pelindung 15 liter/menit dengan nilai kekerasan rata-rata tertinggi 60.43 HVN dan kekuatan maksimum 95.32 MPa memiliki ratarata laju korosi sebesar $0.158 \mathrm{mmpy}$.

-Aluminium seri 5050 dengan aliran gas pelindung 20 liter/menit dengan nilai kekerasan rata-rata tertinggi 62.8 HVN dan kekuatan maksimum $110.18 \mathrm{MPa}$ memiliki rata-rata laju korosi sebesar 0.1187 mmpy.

-Aluminium seri 5050 dengan aliran gas pelindung 25 liter/menit dengan nilai kekerasan rata-rata tertinggi 67.33 HVN dan kekuatan maksimum 128.31 MPa memiliki rata-rata laju korosi sebesar 0.0823 mmpy.

2. Pengelasan GMAW (gas metal arc welding) aluminium seri 5050 dengan kecepatan aliran gas pelindung 25 liter/menit memiliki rata-rata nilai laju korosi yang lebih kecil jika dibandingkan dengan kecepatan aliran gas pelindung 15 liter/menit dan 20 liter/menit.

- Rata-rata laju korosi spesimen aluminium seri 5050 dengan kecepatan aliran gas pelindung 25 liter/menit yaitu 0.0823 mmpy

- Rata-rata laju korosi spesimen aluminium seri 5050 dengan kecepatan aliran gas pelindung 20 liter/menit yaitu 0.1187 mmpy

- Rata-rata laju korosi spesimen aluminium seri 5050 dengan kecepatan aliran gas pelindung 15 liter/menit yaitu 0.158 mmpy.

3. Kondisi optimal pengaruh variasi aliran gas pelindung pada pengelasan GMAW (gas metal arc welding) terhadap laju korosi sambungan butt joint double $\mathrm{v}$ groove pada pelat aluminium seri 5050 adalah kecepatan aliran gas pelindung 25 liter/menit sebesar 0.0823 mmpy dikarenakan semakin besar perlindungan gas yang diberikan kepada proses pengelasan maka akan semakin besar pula perlindungan yang diberikan dari pengaruh lingkungan luar yang bisa mempengaruhi hasil pengelasan.

\section{SARAN}

Beberapa hal yang dapat dijadikan saran yang sifatnya membangun penelitian selanjutnya dalah sebagai berikut:

1. Pada penelitian selanjutnya variasi aliran gas pelindung bisa ditingkatkan lagi untuk melihat apakah semakin tinggi aliran gas pelindung akan semakin baik hasilnya atau mungkin akan mengalami penurunan pada titik tertentu.

2. Pada penelitian selanjutnya variasi bentuk kampuh bisa dilakukan untuk melihat seberapa besar pengaruh yang terjadi terhadap kekuatan dan laju korosi dengan variasi bentuk kampuh karena pada penelitian kali ini hanya menggunakan bentuk kampul double $v$.

3. Proses pre heat pada pengelesan aluminium salah satu yang terpenting namun pada penelitian kali ini tidak dilakukan sehingga perlu dilakukan penelitian lebih lanjut tentang variasi pre heat yang optimal terhadap hasil pengelasan selain variasi kecepatan aliran gas pelindung.

4. Analisa tegangan sisa dan distorsi dengam bantuan software ANSYS bisa dilakukan untuk melihat korelasi hasil pengujian dengan hasil software.

\section{DAFTAR PUSTAKA}

[1] Amantyo, H., dan Daryanto. 2006. "Ilmu Bahan", Jakarta: Bumi Aksara.

[2] Suherman, Wahid. 1987. "Pengetahuan Bahan", Surabaya: Jurusan Teknik Mesin Institut Teknologi Sepuluh Nopember.

[3] Okumura, T., Wiryosumarto, H. 1994. "Teknologi Pengelasan Logam", Jakarta: Pradnya Paramita.

[4] Mars, G., Fontana. 1967. "Corrosion Engineering 3rd edition", New York: Mc Graw-Hill Book Company.

[5] Febrianto, dkk. 2000. "Analisis Korosi Material Tangki Reaktor Triaga Mark II Bandung". Prosiding Presentasi Ilmiah Teknologi Keselamatan Nuklir-V, Serpong, 28 Juni 2000.

[6] AWS D1.2. 1997. "Structural Welding Code - Aluminum", Miami: American Welding Society.

[7] ASTM E3-01. 2002. "Standard Guide for Preparation of Metallographc Specimens". Washington: ASTM Publishing.

[8] ASTM E92. 2004. "Standard Test Method for Vickers Hardness of Metallic Materials". Washington: ASTM Publishing.

[9] ASTM G102. 2002. "Standard Practice for Calculation of Corrosion Rates and Related Information from Electrochemical Measurement", Washington: ASTM Publishing.

[10] ASTM D1141-98, 2003. "Standard Practice for the Preparation of Substitute Ocean Water", Washington: ASTM Publishing.

[11] ASTM E 562 - 02, 2002. "Standard Test Method for Determining Volume Fraction by Systematic Manual Point Count", Washington: ASTM Publishing.

[12] Mirihanage, Wajira. 2004. "Modification Of Al 5083 Weld Joint Characteristics", Department of Materials Engineering, University of Moratuwa, Moratuwa, Sri Lanka 